\title{
Reference evapotranspiration estimation using equations with limited data in arid zones
}

\section{Estimación de evapotranspiración de referencia utilizando ecuaciones con limitación de datos en zonas áridas}

SIFUENTES-MORÍN, Norma Guadalupe †*, FRÍAS-RAMÍREZ, José Ernesto, SERVÍN-PRIETO, Alan Joel and MONTEMAYOR-TREJO, José Alfredo

Instituto Tecnológico de Torreón. Carretera Torreón-San Pedro de las Colonias Km 7.5, Ejido Ana, CP 27170. Torreón, Coah.

ID $1^{\text {st }}$ Author: Norma Guadalupe, Sifuentes-Morín / ORC ID: 0000-0003-4724-5294, CVU CONACYT ID: 713430

ID $1^{\text {st }}$ Coauthor: José Ernesto, Frías-Ramírez / ORC ID: 0000-0002-6631-6599, CVU CONACYT ID: 67627

ID $2^{\text {nd }}$ Coauthor: Alan Joel, Servin-Prieto / ORC ID: 0000-0002-5534-7875, CVU CONACYT ID: 255753

ID $3^{\text {rd }}$ Coauthor: José Alfredo, Montemayor-Trejo / ORC ID: 0000-0001-8222-286X, CVU CONACYT ID: 201396

DOI: $10.35429 / J E D T .2020 .7 .4 .1 .7$

Received September 10, 2020; Accepted December 20, 2020

\begin{abstract}
Reference evapotranspiration (ETo), is the most important parameter to estimate water consumption. Nowadays the FAO-56 Penman-Monteith method is the most used in the world to estimate Eto, and recommended as the standard method. The main limitation to use this method is the availability of the requiere weather data. There are step by step calculations to estimate ETo when there is a lack of climate data; with the purpose to estimate the crop water consumption in arid regions, it was evaluated the presicion and aplicability of three equations to estimate this parameter when there is limited climate data. Estimates of Eto were performed for five sites, New Mexico State University main campus and its research centers Leyendecker, Artesia and Fabian Garcia, in new Mexico, USA; as well as the Agriculture and Range Science School of the Juarez University of Durango State in Mexico. The estimates of ETo were done with all required wheater data and with lack of solar radiation and relative humidity data. The presicion of the equations was evaluated by using the relative error and the index of agreement, consiedring as reference the FAO-56 with full weather data.
\end{abstract}

Evapotranspiration, Actual pressure vapor, Dew point temperature

\begin{abstract}
Resumen
La evapotranspiración de referencia (ETo), es el parámetro más importante para estimar el consumo de agua. Actualmente el método Penman-Monteith (FAO 56), es las más usado en el mundo para estimar ETo, y recomendado por la Organización para la Agricultura y la Alimentación como método estándar. La principal limitación para su uso es la disponibilidad de los datos climáticos que requiere. Existen rutinas para estimar ETo cuando se carecen de datos climáticos; con el propósito de estimar ETo en zona áridas, se evaluó la precisión y aplicabilidad de tres ecuaciones para su estimación con carencia de datos de clima. Cálculos de ETo fueron realizaros para cinco sitios: Campus Las Cruces de la Universidad Estatal de Nuevo México y sus centros de investigación Leyendecker, Artesia y Fabián García, en Nuevo México, Estados Unidos; así como la Facultad de Agricultura y Zootecnia de la Universidad Juárez del Estado de Durango en México. Las estimaciones de ETo se hicieron con datos climáticos completos y con limitación de datos de radiación solar y humedad relativa. La precisión de las ecuaciones, se evaluó mediante el error relativo y el índice de concordancia, considerando como método de referencia el FAO 56, con datos climáticos completos.
\end{abstract}

Evapotranspiración, Humedad relativa, Temperatura de rocío

Citation: SIFUENTES-MORÍN, Norma Guadalupe, FRÍAS-RAMÍREZ, José Ernesto, SERVÍN-PRIETO, Alan Joel and MONTEMAYOR-TREJO, José Alfredo. Reference evapotranspiration estimation using equations with limited data in arid zones. Journal-Economic Development Technological Chance and Growth. 2020. 4-7: 1-7.

\footnotetext{
* Correspondence to Author (email: norgusimor@gmail.com)

$\dagger$ Researcher contributing first author.
} 


\section{Introduction}

The water resource for use in agriculture is increasingly limiting due to its contamination and the decrease in the amount of precipitation due to global climate change, based on the difficulties that humanity faces, it is necessary to have a real knowledge of the water balance of any region at different levels and is achieved with a good estimate of ETo (RodríguezSantiago et al., 2012). Unrestricted water use has increased globally at a rapid rate of more than twice the population growth in the 20th century and leaving many regions without a reliable water supply due to the pace of economic development, urbanization and over all the contamination of arid and semi-arid zones (FAO, 2013).

The deterioration of the aquifers has begun to affect the production of northern Mexico, such as the Comarca Lagunera where the groundwater potential is constituted by 10 aquifers, most of these are in an environment of overexploitation, with a greater amount of water extracted than recharged water, leading to deeper and deeper extraction, generating problems due to salt content (Cervantes, 2006). Thus represented one of the regions where water is a scarce resource that limits economic activity, due to competition for water between consumer sectors (agriculture with irrigation by pumping and gravity, residential sector, livestock and industries), (García et al., 2006).

Knowing the water requirements of the crop is essential to carry out correct irrigation planning and improve the efficiency of water use, supplying the crop with enough water to fully satisfy its needs. One of the most important parameters is evapotranspiration (ETo), which is defined as the loss of water from the soil by two different processes: a) evaporation of the water contained in the soil and b) transpiration of the water contained in the plants (Rodríguez, 2012 ). To determine evapotranspiration there are direct and indirect methods; Among which the empirical and semi-empirical ones stand out, which use meteorological data, and these methods include complex energy balance equations that require a greater number of climatic variables, or simple equations that use a minimum of meteorological variables (Hargreaves and Samani, 1985).
Currently FAO recommends the use of the Penman-Monteith method, also known as FAO-56; It is the standard method to estimate the reference Evapotranspiration (ETo) used for irrigation programming, agricultural planning or regional water balances (Hargreaves and Samani, 1985); (Gonzales et al., 2000).

The main limitation for using the FAO56 method is the availability and quality of the climatic data required by the method (Zotarelli, 2010).

There are calculation routines to estimate the reference evapotranspiration (ETo) when all the required data are not available (solar radiation and relative humidity), (Zotarelli et al., 2010); (Pacheco-Tolentino, 2017); (Todorovic et al., 2013), which estimate solar radiation and current vapor concentration (Zotarelli, 2010); (Todorovic et al., 2013); (Allen et al., 2005). Commonly the net radiation and the actual vapor concentration are calculated based on temperature measurements. The differences in the reference evapotranspiration with limitation of climatic data are in a range of 3-10\% and an adjustment equation can still be developed to improve the precision (Pacheco-Tolentino, 2017). The purpose of this research is to validate the adjustment equation with calculation routines, of the combined Penman-Monteith FAO-56 method, to determine reference evapotranspiration with limited data, calculating current vapor pressure from dew point based on minimum, average and maximum temperatures and evaluate their precision for use in the lagoon region.

\section{Methodology}

\section{Location}

Five study sites were monitored, four in the United States of America; New Mexico State University experimental fields: (NMSU): Main Campus, Leyendecker, Artesia, Fabian Garcia, from the State of New Mexico and one in the United Mexican States; the experimental field of the Faculty of Agriculture and Zootechnics of the Universidad Juárez de Estado de Durango (UJED) in the state of Durango, Mexico. Using climate data from three different years: 2016, 2017 and 2018. 
The New Mexico State University (NMSU) main campus is located in Las Cruces, NM. USA. With geographical location at the latitude of $32.754^{\circ} \mathrm{N}$, the longitude of -104.384 $\mathrm{W}$ with an elevation of 1026.0 meters above sea level. The Leyendecker experimental crop research center of the same university, in Valle de Mesilla, located at the latitude of $32.282^{\circ} \mathrm{N}$, the longitude of $-106.760 \mathrm{~W}$ with an elevation of 1186.0 meters above sea level. The Artesia Science Center, in Eddy County with a latitude of $32.75^{\circ}$, longitude - 104.38 and an elevation of 1027.05 masl. The meteorological station of the Faculty of Agriculture and Animal Husbandry with geographical location at $25^{\circ} 46^{\prime} 56$ "N latitude, longitude $103^{\circ} 23$ 'W with an elevation of 1100 meters above sea level.

\section{Determination of evapotranspiration}

The reference evapotranspiration was estimated with two different equations: Climate data from the five experimental sites for the years 20162018 were used; the first with complete meteorological data, using the Penman-Monteith method (PM-FAO-56). This estimate was considered as the reference to determine precision. The second routine consisted of estimating ETo with limited data, particularly solar radiation (Rs) and relative humidity ( $\mathrm{Hr}$; considering equations based on dew temperature (Kenett 2010), and based on values of minimum temperatures (Zotarelli, 2010) and using the Penman Monteith Temperature method (Allen, 2008), to estimate the current vapor pressure. To later evaluate the precision and applicability of these equations for arid zones. Solar radiation was estimated with the equation of (Samani, 1982).

\section{Determination of reference evapotranspiration with complete data}

Reference Evapotranspiration calculations by the PM-FAO 56 method according to (Zotarelli et al., 2010):

$\frac{\mathrm{ETo}=0.408 \Delta(\mathrm{Rn}-\mathrm{G})+\gamma \frac{900}{\mathrm{~T}+273} \mathrm{U}^{2}(\mathrm{es}-\mathrm{ea})}{\Delta+\gamma\left(1+0.34 \mathrm{U}^{2}\right)}$

Where:

ETo: reference evapotranspiration [mm day-1], $\mathrm{Rn}$ : net radiation on the crop surface $[\mathrm{MJ} \mathrm{m}-2$ day-1],

G: density of heat flux in the soil [MJ m-2 day1],
$\mathrm{T}$ : air temperature $\left[{ }^{\circ} \mathrm{C}\right]$,

$\mu 2$ : wind speed recorded at a height of $2 \mathrm{~m}[\mathrm{~m} \mathrm{~s}-$ $1]$,

is: saturation vapor pressure [ $\mathrm{kPa}]$,

ea: vapor pressure $[\mathrm{kPa}]$,

es-ea: saturation vapor pressure deficit $[\mathrm{kPa}]$,

$\Delta$ : slope of the vapor pressure curve $\left[\mathrm{kPa}^{\circ} \mathrm{C}-1\right]$, $\gamma$ : psychometric constant $\left[\mathrm{kPa}^{\circ} \mathrm{C}-1\right]$.

\section{Determination of reference evapotranspiration with data limitation}

Considering that this method requires a lot of climatic data, which in most stations are not available, the reference evapotranspiration was estimated using equations to determine solar radiation and vapor concentration; using the Penman-Monteith Temperature (PMT) method that uses as input only the minimum and maximum air temperature for the estimation of the reference evapotranspiration (Allen et al., 1998); (Popova et al., 2006); (Todorovic et al., 2013) from the years 2016 to 2018.

\section{Calculation routine for when the solar radiation variable is not available}

Solar radiation derived from thermal differences (RS), when solar radiation data is not available at the meteorological station, was calculated using the equation of (Samani, 2004):

$$
R_{s}=K_{R S} \sqrt{\left(T_{\max }-T_{\min }\right)} R_{a}
$$

Where:

KRS = Where land mass dominates and air masses are not strongly influenced by a large body of water, Allen (1995) suggested kRs = 0.17 ( $\mathrm{P} / \mathrm{Po}$ ) 0.5; for "coastal" regions it is proposed to use $\mathrm{kRs}=0.20(\mathrm{P} / \mathrm{Po}) 0.5$ to take into account the effects of elevation on the volumetric heat capacity of the atmosphere, where $\mathrm{P}$ and $\mathrm{Po}$ are mean atmospheric pressure of the class and its level, respectively $[\mathrm{kPa}]$.

$\mathrm{Ra}=$ extraterrestrial radiation [MJ m-2 day-1]

Tmax $=$ maximum temperature $\left[{ }^{\circ} \mathrm{C}\right]$

Tmin $=$ minimum temperature $\left[{ }^{\circ} \mathrm{C}\right]$

The net shortwave solar radiation (Rns), is given by:

$\mathrm{R}_{\mathrm{ns}}=(1-\alpha) \mathrm{R}_{\mathrm{s}}$ 
Where:

$\mathrm{Rns}=$ net solar radiation or short wave $[\mathrm{MJ} \mathrm{m}-2$ day-1],

$\alpha=$ albedo or reflection coefficient of the crop, which is 0.23

$\mathrm{Rs}=$ incoming solar radiation [MJ m-2 day-1]

Solar radiation for clear sky conditions (RSO) was calculated by:

$\mathrm{R}_{\text {so }}=\left(0.75+2 \mathrm{E} 10^{-5} \mathrm{z}\right) \mathrm{R}_{\mathrm{a}}$

Where:

$0.75=$ as + bs

$\mathrm{Z}=$ elevation above sea level [m]

$\mathrm{Ra}=$ extraterrestrial radiation [MJ m-2 day-1]

The long wave net radiation (Rnl), was calculated by:

$R_{n l}=\sigma\left[\frac{\left(T_{\max }+273.6\right)^{4}+\left(T_{\min }+273.16\right)^{4}}{2}\right](0.34-$

$\left.0.14 \sqrt{e_{a}}\right)\left[1.35 \frac{R_{s}}{R_{s o}}-0.35\right]$

Where:

$\mathrm{Rnl}=$ Net long-wave radiation [MJ m-2 day-1], $\sigma=$ Stefan-Boltzmann constant $[4.903 \times 10-9$ MJ K-4 m-2 dia-1],

Tmax $=$ absolute maximum temperature during a period of 24 hours [

Tmin $=$ absolute minimum temperature during a 24 hour period

ea $=$ actual vapor pressure $[\mathrm{kPa}]$,

$\mathrm{Rs}=$ measured or calculated solar radiation $[\mathrm{MJ}$ $\mathrm{m}-2$ day-1],

Rso = radiation on a clear day [MJ m-2 day-1] .

Net radiation $(\mathrm{Rn})$ is the difference between net short-wave radiation (Rns) and net long-wave radiation $(\mathrm{Rnl})$ and is calculated by:

$\mathrm{R}_{\mathrm{n}}=\mathrm{R}_{\mathrm{ns}}-\mathrm{R}_{\mathrm{nl}}$

Where:

$\mathrm{Rns}=$ net solar or shortwave radiation, $[\mathrm{MJ} \mathrm{m}-2$ day-1]

$\mathrm{Rnl}=$ long wave net radiation, [MJ m-2 day-1]

\section{Calculation of the vapor pressure deficit (VPD)}

The vapor pressure deficit (VPD) is estimated as the difference between the saturation vapor pressure (s) and the actual vapor pressure (ea):

$V D P=e_{s}-e_{a}$

\section{Vapor pressure at saturation (s)}

Since the average saturation vapor pressure is related to the air temperature, it can be calculated from the air temperature, therefore, the average saturation vapor pressure is calculated as the average between the vapor pressure saturation of maximum and minimum daily air temperatures.

$e\left(T_{\max }\right)=0.6108 \exp \left[\frac{17.27 T_{\max }}{T_{\max }+237.3}\right]$
$e\left(T_{\min }\right)=0.6108 \exp \left[\frac{17.27 T_{\min }}{T_{\min }+237.3}\right]$

Where:

Tmax = maximum daily air temperature $\left[{ }^{\circ} \mathrm{C}\right]$

Tmin = daily minimum air temperature $\left[{ }^{\circ} \mathrm{C}\right]$

\section{Vapor pressure at saturation (s)}

The mean steam saturation pressure for a day, week or month must be calculated as the average of the steam saturation pressure at the mean maximum temperature and the steam saturation pressure at the mean minimum air temperature for that period. by (Zotarelli et al., 2013); (Pacheco-Tolentino, 2013); (Todorovic et al., 2013).

$e_{S}=\frac{0.6108 \exp \left[\frac{17.27 T_{\max }}{T_{\max }+237.3}\right]+0.6108 \exp \left[\frac{17.27 T_{\min }}{T_{\min }+237.3}\right]}{2}$

\section{Equation evaluation}

To carry out the evaluation, two processes were carried out with which the precision and applicability of the equations was verified. First, to determine the applicability, the estimated evapotranspiration with data limitation was compared with the reference method with complete data FAO-56, obtaining the absolute relative error. Subsequently, the Wilmott concordance index was obtained by regression between the estimated data and the reference Et (Wilmott, 1982). This statistical data analysis was done for each site and years of observation.

\section{Results}

For the five study sites the ET mm / day was determined under the FAO-56 methodology and with the data limitation formula for the years 2016, 2017 and 2018. 


\begin{tabular}{|l|r|r|r|}
\hline \multicolumn{1}{c}{ FAO-56 } & \multicolumn{1}{c|}{ Data Lim } \\
\hline Site & ETo prom & ETo prom & error \\
\hline & mm / day & mm / day & \\
\hline NMSU & 4.925 & 4.4625 & 10 \\
\hline Leyendecker & 4.595 & 5.2575 & 10 \\
\hline Artesia & 5.585 & 5.455 & 16 \\
\hline Fabián G. & 4.63 & 4.2975 & 12 \\
\hline Venecia & 5.94 & 6.415 & 16 \\
\hline
\end{tabular}

Table 1 Average values of potential evapotranspiration (ETo) of the five sampling sites using the full methodology and the data limitation

Source: Own Elaboration

The behavior of ETo over time showed a normal trend with high values for the months of May to August, when the environmental temperature is higher. For the NMSU site, the ETo estimate that most closely approximated the reference value was the one corresponding to the equation based on dew point temperature; while for Leyendecker they were those corresponding to the equation based on dew point temperature Tdew and PMT. In Artesia's case, the equations based on dew point temperature PMT and Tmin are the ones that are closest to the reference. So much so that, for the Fabián G. and Venecia sites, all equations with data limits were close to the reference value throughout the year, therefore it coincides with that reported by (Allen et al., 1998, Zotarelli, 2010, Pacheco Tolentino, 2017, Simón 2019).

\section{Concordance Index}

To determine the precision of the equations with limitation of climatic data, the concordance index was calculated (Wilmott, 2006). Compared to FAO-56 reference method with full data. Table 2 shows the concordance index is close to 1 in all sites and in all years with minimum values of 0.90 and maximum values of 0.98 , representing a high concordance of the adjustment equation based on the reference method..

\begin{tabular}{|l|r|r|r|r|r|r|r|}
\hline \multicolumn{1}{|c|}{ I.A. } & \multicolumn{1}{c|}{ E.F. } \\
\hline Site & Year & T min & TDEW & PMT & T min & TDEW & PMT \\
\hline NMSU & 2016 & 0.97 & 0.98 & 0.98 & 0.9 & 0.92 & 0.92 \\
\hline & 2017 & 0.97 & 0.97 & 0.97 & 0.89 & 0.89 & 0.91 \\
\hline & 2018 & 0.96 & 0.97 & 0.97 & 0.87 & 0.87 & 0.89 \\
\hline Leyendecker & 2016 & 0.97 & 0.97 & 0.98 & 0.88 & 0.88 & 0.94 \\
\hline & 2017 & 0.96 & 0.96 & 0.98 & 0.86 & 0.86 & 0.93 \\
\hline & 2018 & 0.96 & 0.96 & 0.98 & 0.86 & 0.86 & 0.92 \\
\hline Artesia & 2018 & 0.95 & 0.96 & 0.97 & 0.84 & 0.82 & 0.91 \\
\hline Fabian G. & 2018 & 0.91 & 0.97 & 0.98 & 0.64 & 0.9 & 0.94 \\
\hline Venecia & 2018 & 0.9 & 0.91 & 0.93 & 0.65 & 0.66 & 0.75 \\
\hline
\end{tabular}

Table 2 Values of the concordance indices (I.A.) and efficiency (EF) in the calculation of evapotranspiration for equations with data limitation

Source: Own Elaboration
These values are similar to those reported by (Pacheco Tolentino, 2017, Simón, 2019) where they mention that equations with a data limit can be an alternative when climate data is not available or is deficient

\section{Conclusions}

The adjustment equation considering dew temperature ( $T$ Dew) resulted in greater precision in the estimation of the reference evapotranspiration (ETo) when data on solar radiation (Rs) and relative humidity (Rh) are not available in arid zones. The precision in the estimation demonstrated consistency in the different sites in which they were tested, which means that it may have applicability in different locations in arid zones.

\section{References}

Allen, R. G., L. S. Pereira, D. Raes y M. Smith 1998. "Crop evapotranspiration Guidelines for computing crop water requirements-FAO irrigation and drainage paper 56." Rome: 1-15

Allen, R., A. I. Walter, R. Elliott, T. Howell, D. Itenfisu y M. Jensen 2005. "The asce standardized reference evapotranspiration equation." The American Society of Civil Engineers: 1-70

Allen, R., L. Pereira, D. Raes y M. Smith 2006. "Evapotranspiración del cultivo. Guía para la determinación de los requerimientos de agua de los cultivos." Roma: Organización de las Naciones Unidas para la Agricultura y la Alimentación (FAO): 1-298.

Barrales, V., L. Peña, R., I. Fernández, R., B., P. 2004. Validación de modelos: Un enfoque aplicado. Agricultura Técnica, 64(1), 66-73.

Berengena, J. y P. Gavilán 2005. "Reference evapotranspiration estimation in a highly advective semiarid environment." Journal of Irrigation and Drainage Engineering 131: 147163.

Belmonte-Serrano, F. y A. Romero-Díaz 2006. "Medida de la evapotranspiración real en coberturas vegetales semiáridas (Cuenca de Mula, Murcia), según las variaciones de humedad del suelo medidas mediante el procedimiento (TDR)." Papeles de Geografía 43: 5-17. 
Domingo, F., Villagarcía, L. y Were, A. 2002. ¿Cómo se puede medir y estimar la evapotranspiracion?: estado actual y evolución. Ecosistemas 2003/1

CONAGUA 2007. "Estadísticas del agua en México." SEMARNAT.

FAO 2002. "El agua y la agricultura." Cumbre Mundial Sobre La Alimentación: 1-5.

FAO 2011. "The state of the world's land and water resources for food and agriculture (solaw)." Managing systems at risk Rome and Earthscan, Londres,: 1-308

FAO 2013. "Afrontar la escasez de agua (Un marco de acción para la agricultura y la seguridad alimentaria)." Roma 1-97.

FAO 2015. "Agricultura mundial: hacia los años 2015/2030." Departamento Económico y Social: 1-15.

Gómez-Oliver, L. y A. Tacuba-Santos 2017. "The rural development policy in Mexico." Journal of Economic 14: 42.

Flavelle, P. 1992. Una medida cuantitativa de la validación del modelo y su uso potencial para fines regulatorios. Recursos hídricos. 15:5-13

Flores, F., R. Pérez y M. Lillo 2007. "Comparación de tres modelos de estimación de evapotranspiración mediante imágenes MODIS." Teledetección-Hacia un mejor entendimiento de la dinámica global y regional: $1-8$.

García-Salazar, J., J. Alberto, E. Guzmán-Soria y M. Fortis-Hernández 2006. "Demanda y distribución del agua en la Comarca Lagunera, México." Agrociencia 40: 269-276.

Gonzáles, M.A. y B.Hernández (2000), "Estimación de las necesidades hídricas del tomate", Revista Interamericana Terra, vol. 17, núm. 4, pp.45-50.

Hargreaves, G.H. y Z.A. Samani. 1985. Reference crop evapotranspiration from temperature. Appl. Eng. Agric. 1(2):96-99.

Hargreaves, G. H. y R. G. Allen 2003. "History and Evaluation of Hargreaves Evapotranspiration Equation." Journal of Irrigation and Drainage Engineering: 53-63
Hernández, G. R. 2013. "Transpiración." Botanical Book: 1-10.

INEGI 2013. "Sistema de Cuencas Nacionales de México." 1-75.

Samani, Z. 2000. "Estimating solar radiation and evapotranspiration using minimum climatological data." journal of Irrigation and Drainage Engineering 126: 265-267.

Samani, Z. 2004. "Discussion of "History and evaluation of Hargreaves evapotranspiration equation" by George H. Hargreaves and Richard G. Allen. J." Irrig. Drain. Eng 130: 447-448.

Salazar-Moreno, R., A. Rojano-Aguilar y I. L. López-Cruz 2014. "La eficiencia en el uso del agua en la agricultura controlada." Tecnología y Ciencias del Agua 5: 177-183.

Schlesinger, W. H. y S. Jasechko 2014. "Transpiration in the global water cycle." Agricultural and Forest Meteorology: 189-117.

Pacheco-Tolentino, N. 2017. "Estimación de ETo potencial por los métodos FAO56 y Hargreaves-Samani con limitación de datos climáticos." 1-79.

Rodríguez-Santiago, S., R. Arteaga-Ramírez, D. M. Sangerman-Jarquín, R. Cervantes-Osornio y A. Navarro-Bravo 2012. "Evapotranspiración de referencia estimada con Fao-PenmanMonteith,Priestley-Taylor, Hargreaves y RNA" Revista Mexicana de Ciencias Agrícolas 3: 1535-1549.

Sánchez, M. y L. Carvacho 2006. "Estimación de evapotranspiración potencial, ETP, a partir de imágenes NOAA-AVHRR en la VI Región del Libertador General Bernardo O’Higgins." Revista de Geografía Norte Grande: 49-60.

Suárez, T., L. A. González, J. Beltrán 2006. "sistema de medición de la humedad relativa usando un DSSP." Revista de ingeniería electrónica, automática y de comunicaciones: 90-107. 
Tijerina-Chévez, L., R. Villaman-Peña, A. Quevedo-Nolasco y G. Crespo-Pichardo 2001. "Comparación de algunos Métodos Micrometeorológicos para estimar la Evapotranspiración, en el área de Montecillo, México." TERRA/Instituto de Recursos Naturales, Colegio de Posgraduados 19: 281291.

Todorovic, M., K. Biljana y L. S. Pereira 2013. "Reference evapotranspiration estimate with limited weather data across a range of Mediterranean climates." Journal of Hydrology 481: 166-176.

Vásquez-Méndez, R., E. J. Ventura-Ramos y J. A. Acosta-Gallegos 2011. "Suitability of evapotranspiration estimation methods for semiarid Central Mexico." Revista Mexicana de Ciencias Agrícolas 3: 399-41.

Willmott, C. J. 1982. "Some comments on the evaluation of model performance." American Meteorological Society 63: 1309-1317.

Willmott, C. J. and Matsuura, K. (2005). Advantages of the mean absolute error (MAE) over the root mean square error (RMSE) in assessing average model performance. Climate Research, 30(1), 79-82.

Zotarelli, L., D. Michael, C. Consuelo, K. W. Romero y K. T. Migliaccio 2010. "Step by step calculation of the Penman-Monteith evapotranspiration (FAO56 Method)." University of Florida, IFAS Extension 1-12. 